\title{
Neurogenic differentiation of human conjunctiva mesenchymal stem cells on a nanofibrous scaffold
}

\author{
MASOUD SOLEIMANI*,\#,1, SAMAD NADRI*,\#,2,3, IMAN SHABANI ${ }^{4}$ \\ ${ }^{1}$ Hematology Department, Faculty of Medical Science, Tarbiat Modares University, \\ ${ }^{2}$ Stem Cell Biology, Nanotechnology and Tissue Engineering Department, Stem Cell Technology Research Center \\ ${ }^{3}$ Medical Physics and Biomedical Engineering Department, Shahid Beheshti University (M.C) and \\ ${ }^{4}$ Polymer Engineering Department, Amirkabir University of Technology, Tehran, Iran
}

\begin{abstract}
The selection of a good quality scaffold is an essential strategy for tissue engineering. Ideally, the scaffold should be a functional and structural biomimetic of the native extracellular matrix and support multiple tissue morphogenesis. However, investigators have previously shown that three-dimensional nanofibrous scaffolds are capable of influencing cellular behavior. In this study, we experimented with a three-dimensional nanofibrous scaffold fabricated from aligned-poly L-lactic acid (PLLA) for its ability to support neurogenic and hinder dopaminergic differentiation of conjunctiva mesenchymal stem cells (CJMSCs) in vitro. In this work, CJMSCs were seeded onto nanofibrous scaffolds, and were induced to differentiate along neurogenic lineages by culturing in specific differentiation media. Scanning electron microscopy imaging, RTPCR and immunocytochemistry were used to analyze cultivated CJMSCs on scaffold and their expression of neurogenic-specific markers. We found a lack of expression of dopaminergic genes in CJMSCs seeded on align PLLA scaffold, while neurocyte-cell markers including Nestin, NSE, MAP-2 and $\beta$-Tubulin III were expressed in these cells. On the basis of these experimental results, we conclude that the nanofibrous PLLA scaffold reported herein could be used as a potential cell carrier in neural tissue engineering and that these scaffolds could be useful for the partial inhibition of the dopaminergic differentiation of CJMSCs.
\end{abstract}

KEY WORDS: poly (L-lactic acid), PLLA, mesenchymal stem cell, dopaminergic gene, nanofibrous scaffold

\section{Introduction}

Tissue engineering techniques are currently being developed to successfully repair and restore the function of damaged or diseased tissue(Tuan et al., 2003; Caplan, 2000; Cancedda et al., 2003). The basic principle involves the use of an appropriate cell source and a biocompatible and biodegradable scaffold to produce a construct that structurally and functionally mimics the target tissue.

In recent years, Mesenchymal stem cells (MSCs) have been defined as a population of primitive cells with capability of selfrenewal and differentiation into multiple cell lineages for treatment of human diseases(Tonti and Mannello, 2008), including models for osteogenesis imperfecta (Horwitz et al., 2002), spinal cord injury (Sasaki et al., 2001), stroke (Chen et al., 2003), and Parkinsonism (Schwarz et al., 1999). To date, MSCs have been isolated from a variety of human tissue(De Bari et al., 2001; Nakahara etal., 1990; Noth et al., 2002; Miura et al., 2003; Nadri et al., 2008; De Ugarte et al., 2003; Noort et al., 2002; Sarugaser et al., 2005; Bhang et al., 2007). Furthermore, considerable effort has been made to develop scaffolds for tissue engineering. Design and fabrication of scaffolds using appropriate biomaterials is a key for

Abbreviations used in this paper: CJMSC, conjunctiva mesenchymal stem cell; ECM, extracellular matrix; MSC, mesenchymal stem cell; PLLA, poly L-lactic acid.

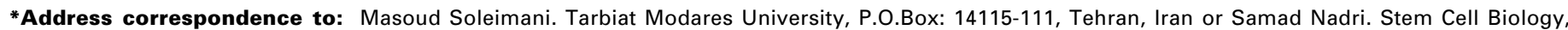

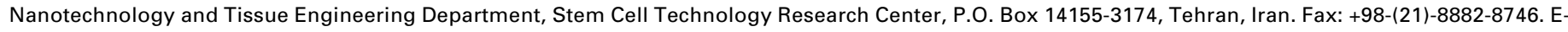
mails: soleim_m@modares.ac.ir or s.nadri@stemcellstech.com
}

\#Note: These authors contributed equally to this work.

Supplementary Material (one figure) for this paper is available at: http://dx.doi.org/10.1387/ijdb.092999ms 

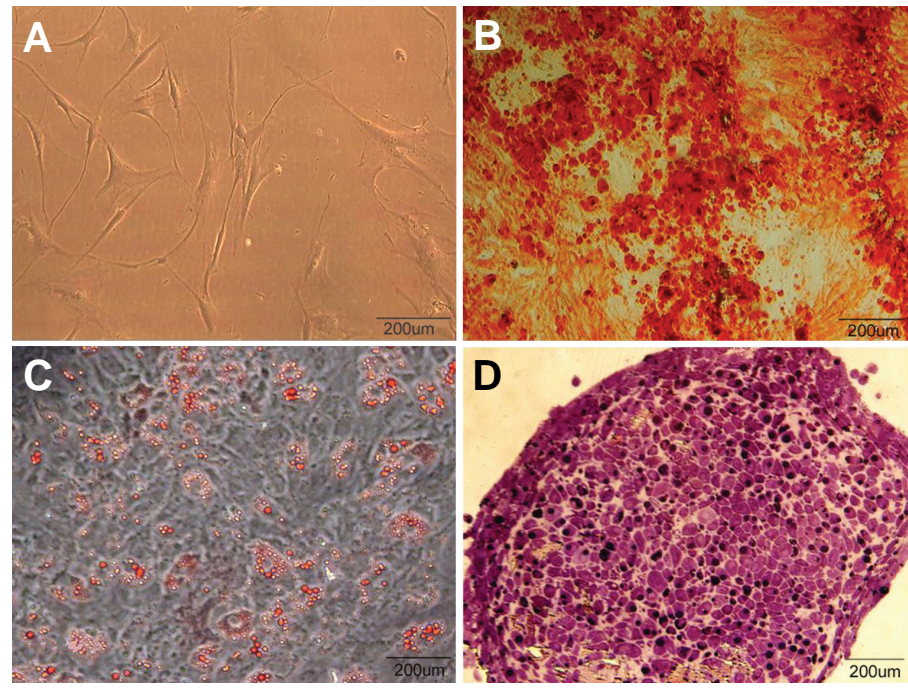

Fig. 1. Morphological characteristics and in vitro differentiation of conjunctiva stromal fibroblast-like cells into mesenchymal lineages. (A) Conjunctiva stromal cells (passage 2) have differentiated into (B) mineralizing cells stained with alizarin red. (C) Adipocytes stained with Oil red $O$. (D) Chondrocytic lineage stained with Toluidin blue. (Magnification $=\times 20$ )

the creation of functional engineered tissues and clinical applications(Andrades et al., 1996). The native extracellular matrix (ECM) is comprised of a complex network of structural and regulatory proteins that are arrayed into a fibrous matrix. It also provides resident cells with specific ligands for cell adhesion and migration, and modulates cell proliferation and function (Nishimura et al., 2003; Nguyen and D'Amore, 2001; Shields et al., 2004). However, by combining engineering principles with knowledge of materials science and stem cell biology, investigators seek to create novel constructs that will fully integrate into the host system and restore function of diseases such as central nervous system.

While three-dimensional biomaterial scaffolds have been used to engineer neurocyte cell-type specific constructs, to our knowledge, there has been little report on the successful application of a single three-dimensional scaffold to support cell differentiation into specific types of neurocyte cells. Thus an ideal biomaterial scaffold should be capable of supporting and directing cell differentiation into specific lineages.

Our work focuses on characterizing the response of human CJMSCs to poly L-Lactic acid (PLLA) scaffold, with a view to develop these materials for neuron tissue engineering applications. Previous study indicated that scaffold environments influenced the cellular behavior (Flynn et al., 2008).

Here, we thoroughly examined the conjunctiva mesenchymal stem cells (CJMSCs) differentiation responses in order to widen a deeper perceptive of the influence of the PLLA scaffold on direct differentiation of CJMSCs into neurocyte lineage.

CJMSCs were isolated from human conjunctiva stromal cells(Nadri et al., 2008). The most important properties of conjunctiva stromal-derived MSCs (CJMSCs) were their expression of undifferentiated stem cells markers as Oct-4, Rex-1, and Nanog and lineage-specific markers like cardiac-actin (mesoderm lineage marker) and Keratin (ectoderm lineage marker) (Nadri et al., 2008)(Supplementary Figure 1). Furthermore, These cells were differentiated into dopaminergic neuron(Nadri et al., 2008) and best candidate for regenerative central nerve system (CNS) injury due to have high proliferation and differentiation capacity into neurocyte cells.

\section{Results}

\section{Cell culture of conjunctiva mesenchymal stem cells (CJMSCs)}

In this work, the mesenchymal stem cells with spindle-shaped morphology from human conjunctiva stromal cells were isolated by adhesion of these cells onto the surface of the plastic culture dishes. After 2 weeks, fibroblast-like cells with spindle-shape morphology appeared on culture dishes (Fig 1A). The cells were utilized for following experiments.

In vitro differentiation of CJMSCs into mesenchymal lineages

To confirm mesenchymal nature, the fibroblast-like cells were treated with appropriate osteo-, chondro- and adipo-inductive media (Nadri et al., 2008), and their differentiation was confirmed via appropriate staining including, alizarin red (for osteogenic differentiation), alcian blue (for chondrogenic differentiation) and oil red (for adipogenic differentiaton) staining (Fig 1 B-C).

\section{Fabrication of electerospun nanofibrous PLLA}

To fabricate nanofiber, we used electrospinning techniques. Electrospinning of PLLA-based nanofiber resulted in a scaffold composed of uniform; align oriented fibers of an average diameter of $700-2000 \mathrm{~nm}$, as seen by scanning electron microscopy (SEM; Fig. 2). Following an 8 week incubation in culture medium at $37^{\circ} \mathrm{C}$, scaffolds maintained their integrity and three-dimensional structure, while exhibiting no noticeable change in dry weight over the entire culture period (data not shown).

\section{Expression of gene transcripts}

To induce neurocyte differentiation, the seeded cells on scaffold and non-seeded cells were cultivated in neuroinductive medium

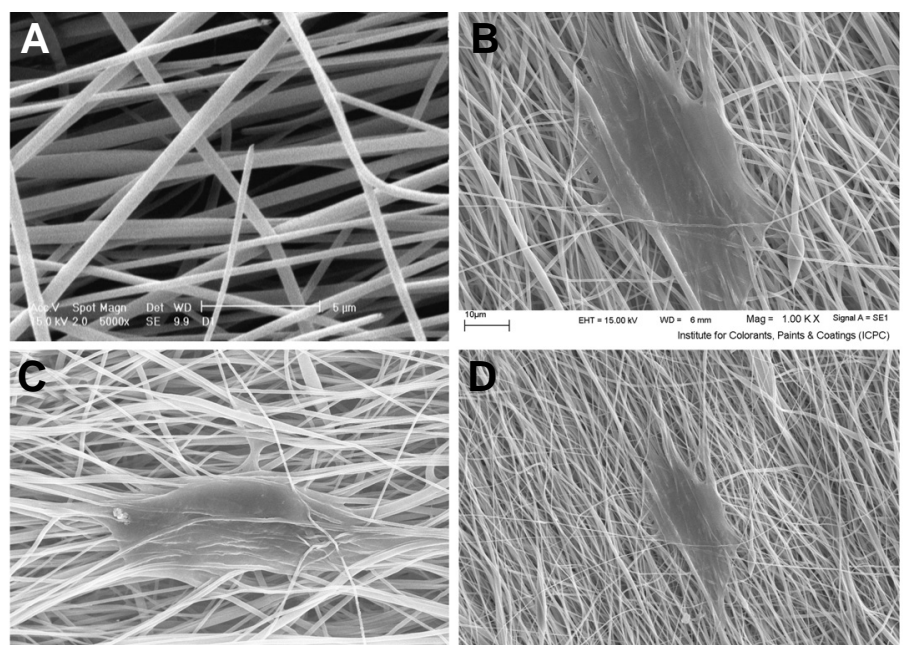

Fig. 2. SEM micrographs of CJMSCs seeded on PLLA nanofibrous scaffolds. (A) The PLLA scaffold contains aligned fibers with uniformly sized fibers of an average diameter of $700-2000 \mathrm{~nm}$ fabricated using electrospinning methods. (B,C,D) The attachment of an anchoragedependent conjunctiva mesenchymal stem cell on the porous structure of PLLA nanofibrous scaffold at different magnifications (100X, 1500X and $500 X$ respectively). 


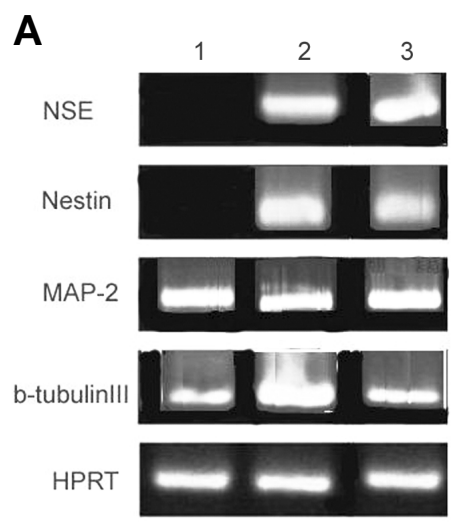

B

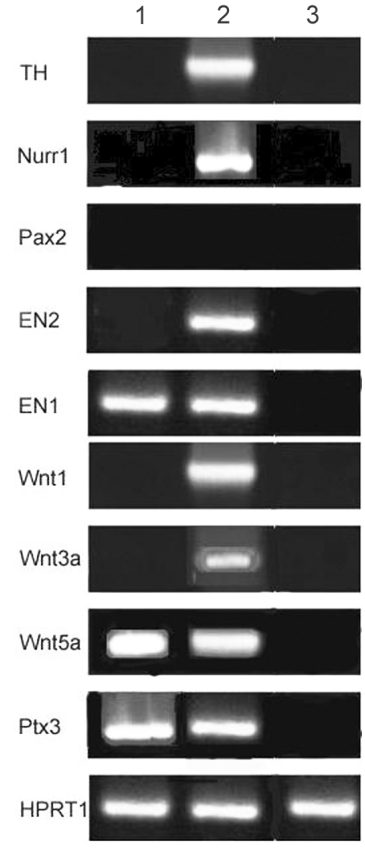

containing RA, IBMX and dbcAMP. After 6 days, we examined with the neural and dopaminergic markers by RT-PCR. RT-PCR analysis was indicative of the expression of Nestin, NSE MAP-2 and btubulin III genes in either seeded and non-seeded on scaffold, whereas the dopaminergic genes including TH, Nurr1, Pax2, En1, En2, Wnt1, Wnt3a, Wnt5a and Ptx3 were not expressed in the seeding of CJMSCs on PLLA scaffold (Fig. 3 A,B).

\section{Immunocytochemistry analysis}

Immunocytochemistry was used to analyze the intracellular $\mathrm{TH}$ and b-Tubulin III proteins. The result showed which B-Tubulin III proteins were detected in the CJFLCs on PLLA nanofiber after treatment in neuroinductive medium for 6 days (Fig. 4).

Fig. 3. Investigation of differentiation-specific gene expression. (A) Expression of neuron markers such as neuron-specific enolase (NSE), beta-tubulin III, microtubule-associated protein-2 (MAP-2) and Nestin were analyzed in (1) control (day 0), (2) differentiation culture (day 6) and (3) the seeded cells on scaffold in differentiation culture. (B) Expression of dopaminergic-associated markers were analyzed in (1) control (day 0), (2) differentiation culture (day 6) and (3) the seeded cells on scaffold in differentiaton culture (6 days). Hypoxanthine phosphoribosyltransferse1 (HPRT-1) is used as a housekeeping gene control.

\section{Discussion}

While stem cells have shown promise for tissue engineering applications, it is necessary to understand the scaffold properties that promote the diffusion of nutrient, metabolites and soluble factors until the seeded cell can produce a new functional matrix and regenerate the desired tissue structures (Langer and Vacanti.1993; Nerem.2000; Vacanti and Langer.1999). Within the seeded constructs, cell material interactions may directly influence the lineage commitment process of the multipotent stem cells(Zuk et al., 2002; Rosen and MacDougald.2006). In the present study, we examined the influence of PLLA nanofibrous scaffold on direct differentiation of CJMSCs to neurogenic lineages.

MSCs have been considered as an appropriate source for cell and gene therapy tools for treatment in a number of congenital and degenerative diseases (Baksh et al., 2004). Promising evidences have been reported with the use of cells in a number of animal models for human diseases, including models for spinal cord injury (Sasaki et al., 2001), stroke (Chen et al., 2003), and Parkinsonism (Schwarz et al., 1999). These cells have been isolated from different tissue sources including periosteum (Nakahara et al., 1990), trabecular bone (Noth et al., 2002), adipose tissue (De Ugarte et al., 2003), synovium (De Bari et al., 2001), deciduous teeth (Miura et al., 2003), lung (Noort et al., 2002), and human umbilical cord perivascular cells derived from the Wharton's jelly (Sarugaser et al., 2005). Recently, we successfully isolated MSCs
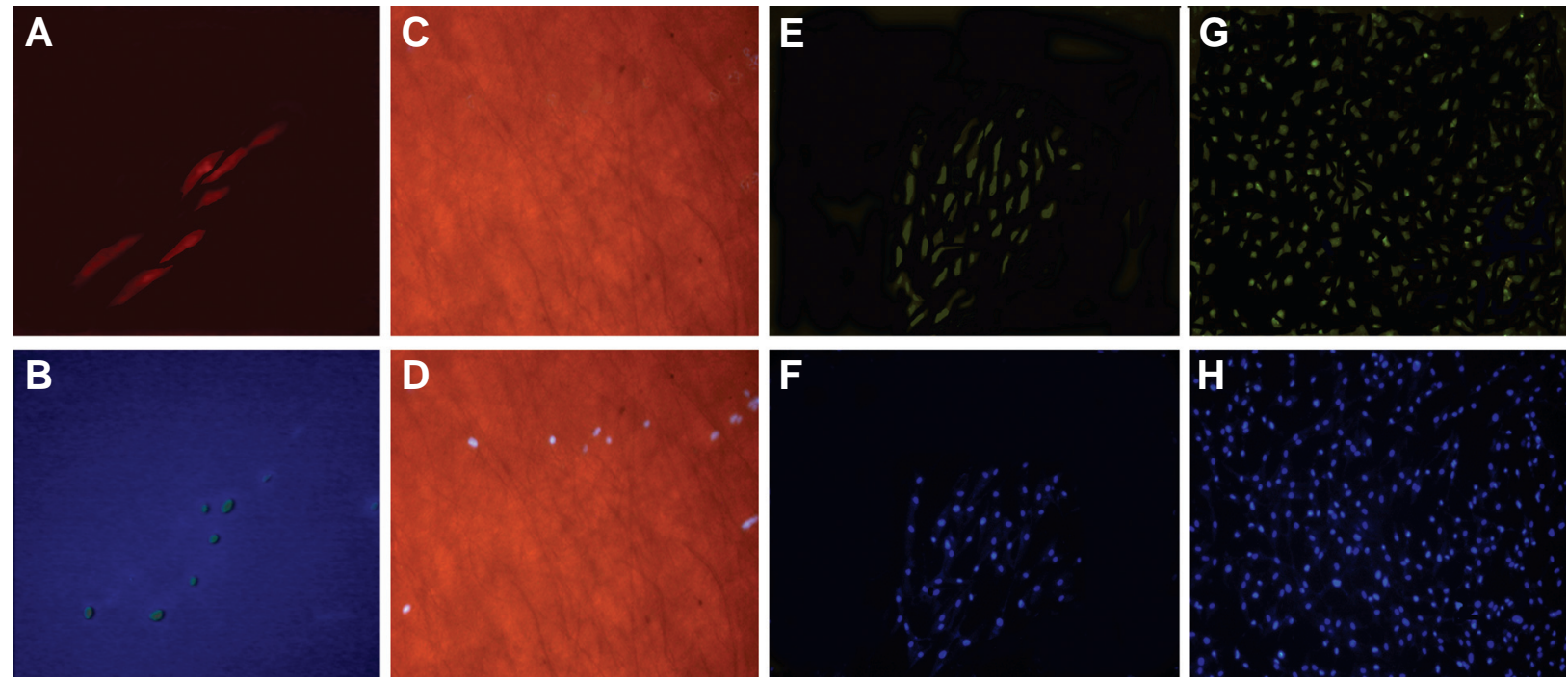

Fig. 4. Immunostaining of cells (seeded and non-seeded on PLLA scaffold) with tyrosine hydroxylase (TH) and beta-tubullin III staining. The seeded cells on PLLA scaffold $(\mathbf{A}, \mathbf{C})$ and non-seeded cells (tissue culture polystyrene) $(\mathbf{E}, \mathbf{G})$ were maintained in neurogenic medium for 6 days and analyzed for expression of $\beta$-Tubulin III $(A, E)$ and TH $(C, G)$ proteins. Cells were co-stained with 4, 6 diamidino-2-phenylindole to visualize nuclei (blue) related to $\mathrm{TH}(\mathbf{B}, \mathbf{D}, \mathbf{F}, \mathbf{H})$ 
of eye conjunctiva stromal cells. Furthermore, these cells have spindle-shape morphology and were simply differentiated into mesenchymal lineages (osteo-adipo-chondrogenic cells) and neuronal cells. In this work CJMSCs seeded on PLLA scaffold and maintained in neurogenic medium for 6 days.

The results from this research showed that the scaffolds could inhibit the expression of dopaminergic genes in CJMSCs. Bhang et al., indicate that PLLA scaffold which fabricated using phase separation methods, have inhibitory effect on proliferation and neural differentiation of hippocampal progenitors cells due to the hydrophobic surface of its(Bhang etal., 2007). Though this method supplied scaffolds for tissue engineering, there were however difficulties encountered in controlling fiber diameter and alignment (Yang et al., 2005). In present study, PLLA scaffolds were fabricated using electrospinning methods and enhanced hydrophilic surface of polymer using oxygenated gas plasma. Previous researcher reported that modification of surface by gas plasma enhanced cell attachment to polymer(Ghasemi-Mobarakeh et al., 2008). In this work, After exposure to neurogenic media, end point RT-PCR analysis indicated that in despite of the non seeding of CJMSCs on scaffold (tissue culture polystyrene (TCPS) plates, control), specific dopaminergic genes including TH, Nurr1, Ptx3, En1, En2, Pax2, Wnt3a and Wnt1 were not expressed in the seeding of CJMSCs on scaffold while neural stem cell markers expressed in these cells. A TH protein is the initial and rate-limiting enzyme in the catecholamine synthesis pathway, and considered the principal regulator of dopamine biosynthesis in the central nervous system(Kan et al., 2007). It has been reported that Nurr1 and Ptx3 are a nuclear receptor and transcription factor, respectively, essential for differentiation of the dopaminergic precursor neurons (Jankovic et al., 2005; Chu et al., 2006; Martinat et al., 2006).EN1 and EN2 have been shown to have significant roles in controlling the developmental fate of midbrain dopaminergic neurons and the expression of the genes genetically linked to Parkinson's disease (Simon et al., 2001). On the other hand, Wnts are essential regulators for proliferation and differentiation of ventral midbrain DA precursor neurons (Castelo-Branco et al., 2003). RT-PCR and immunocytochemistry analysis indicated that dopaminergic genes were not expressed in CJMSCs seeded on PLLA scaffold. Most importantly, the PLLA-based nanofibrous scaffold inhibited dopaminergic differentiation of the seeded CJMSCs when the constructs were placed under specific, differentiation-promoting culture condition. In this work, to ensure a correct differentiation of the CJMSCs on a nanoscaffold and inhibition of scaffold on dopaminergic-associated genes in our study, we used RT-PCR analysis to compare the expression of dopaminergic genes on seeded and non-seeded CJMSCs on PLLA-scaffold. However, further research is required to elucidate the influence of nanofiber on the biochemical pathways and cellular signaling mechanisms that regulate cell morphology, growth, proliferation, differentiation, motility, and genotype. Insight into how natural ECM components secreted by cells replace the biodegradable polymeric scaffolds is also needed. This complete understanding of cell-nanofiber scaffold interactions will pave the way for successful engineering of various tissues and organs, such as vascular grafts, nerve, skin and bone regeneration, cornea transplants, skeletal and cardiac muscle engineering, gastrointestinal and renal/urinary replacement therapy, and even stem cell expansion and differentiation to specific cells types and organ regeneration.
Both none seeding and seeding of CJMSCs on scaffold express neural stem cell markers such as NSE, Nestin, MAP-2 and btubulin III, which are markers of neurogenic differentiation. This finding has brought into question the clinical applicability of CJMSCs cultured on PLLA-nanoscaffold for regeneration of spinal cord injury. This study is a first to report neurogenic differentiation of CJMSCs seeded in a PLLA nanofibrous scaffold. This work represents an important step forward in the optimization of the scaffold design for neuron tissue engineering applications, by helping to elucidate the conditions that support CJMSCS differentiated into neurogenic differentiation.

Collectively, the results in this study indicate that nanofiber scaffolds positively support differentiation of CJMSCs to specific neural lineage. This can be qualified to the ECM-like properties of the nanofiber scaffolds that mimic the natural tissue environment.

\section{Materials and Methods}

\section{Isolation and culture of CJMSCs}

CJMSCs were isolated according to a protocol modified from Nadri and co-worker(Nadri et al., 2008). In brief, after obtaining informed consent from the individuals, $2-3 \mathrm{~mm}^{2}$ of conjunctiva biopsies were obtained from patients undergoing pterygium surgery and incubated in supplemented hormonal epithelial medium (SHEM), which is made of Dulbecco's modified Eagle's medium (DMEM)/F-12 (GIBCO-BRL, Grand Island, NY) containing bicarbonate (Sigma Chemical Co, St. Louis, MO), $0.5 \%$ dimethyl sulfoxide, $2 \mathrm{ng} / \mathrm{ml}$ human epidermal growth factor (EGF; Peprotech, Rocky Hill, NJ), $5 \mathrm{mg} / \mathrm{ml}$ insulin (GIBCOBRL), $5 \mathrm{mg} / \mathrm{ml}$ transferrin (GIBCO-BRL), $5 \mathrm{ng} / \mathrm{ml}$ sodium selenite (GIBCO-BRL), $0.5 \mathrm{mg} / \mathrm{ml}$ hydrocortisone (GIBCO-BRL), $30 \mathrm{ng} / \mathrm{ml}$ cholera toxin A subunit, $5 \%$ fetal calf serum (FCS; GIBCO-BRL), $50 \mathrm{mg} / \mathrm{ml}$ gentamicin (Sigma Chemical Co), and $1.25 \mathrm{mg} / \mathrm{ml}$ amphotericin B (Sigma Chemical Co) for 2-5 min. Then, the biopsies were treated in SHEM containing $50 \mathrm{mg} / \mathrm{ml}$ dispase II (Sigma Chemical Co) and $100 \mathrm{mM}$ sorbitol (Espana et al., 2003). Under a stereomicroscope, epithelial sheets were separated and the isolated stromal tissue segment was cultured in DMEM/F-12 (1:1) (GIBCO-BRL) supplemented with $10 \%$ knockout serum (GIBCO- BRL), $4 \mathrm{ng} / \mathrm{ml}$ basic-FGF(Peprotech), $5 \mathrm{mg} / \mathrm{ml}$ insulin (Sigma Chemical Co), and $10 \mathrm{ng} / \mathrm{ml}$ human LIF (Chemicon; Temecula, CA) (Dravida et al., 2005) and incubated at $37^{\circ} \mathrm{C}$ with $5 \% \mathrm{CO} 2$ in a humidified chamber for 2 weeks. After 2 weeks, biopsy was removed and the mesenchymal stem cells were trypsinized $(0.25 \%$ Trypsinethylenediaminetetracetic acid [EDTA]; GIBCO-BRL) after confluency. The cells were subsequently expanded by two passages in DMEM (GIBCO$\mathrm{BRL}$ ), which was supplemented with $100 \mathrm{IU} / \mathrm{ml}$ penicillin (Sigma Chemical Co), $100 \mathrm{mg} / \mathrm{ml}$ streptomycin (Sigma Chemical Co), and 15\% FCS.

\section{In vitro differentiation of CJMSCs into mesenchymal lineages}

To identify MSCs-nature of the isolated cells, the cells were treated with osteogenic (DMEM composed of $50 \mu \mathrm{g} / \mathrm{ml}$ ascorbic acid 2-phosphate (Sigma Chemical Co), 10nM dexamethasone (Sigma Chemical Co), and $10 \mathrm{mM}$ b-glycerophosphate (Sigma Chemical Co), adipogenic (DMEM, supplemented with $50 \mu \mathrm{g} / \mathrm{ml}$ indomethacine (Sigma Chemical Co) and $100 \mathrm{nM}$ dexamethasone (Sigma Chemical Co) and chondrogenic (DMEM supplemented with $10 \mathrm{ng} / \mathrm{ml}$ transforming growth factor- $\beta 3$ (TGF- $\beta 3$; Sigma Chemical Co), $500 \mathrm{ng} / \mathrm{ml}$ bone morphogenetic protein-6 (BMP-6), $10^{-7} \mathrm{M}$ dexamethasone (Sigma Chemical Co), and $50 \mu \mathrm{g} / \mathrm{ml}$ ascorbate-2-phosphate (Sigma Chemical Co), $50 \mu \mathrm{g} / \mathrm{ml}$ insulin-transferrin-selenium (ITS GIBCO-BRL) medium for 21 days (Nadri et al., 2008). At the end of the cultivation period, for alizarin red staining, the cells were fixed with $10 \%$ formalin for $10 \mathrm{~min}$ and stained with alizarin red (Sigma) for $15 \mathrm{~min}$ at room temperature. For oil red staining, the cells were stained with $0.5 \%$ oil red $\mathrm{O}$ (Sigma) in methanol for $15 \mathrm{~min}$ for adipocyte detection and for toluidine blue staining, some pellets were prepared for embedding in Araldite (Sigma). 
The pellets were fixed for $1 \mathrm{~h}$ using the Karnovsky fixative at room temperature, washed with $0.1 \mathrm{M} \mathrm{OsO} 4$ (Sigma) in $0.1 \mathrm{M}$ phosphate buffer for $1 \mathrm{~h}$ at $20^{\circ} \mathrm{C}$ and then subjected to graded ethanol dehydration before being embedded. Sections of $0.3 \mu \mathrm{m}$ were made, and stained with toluidine blue.

\section{Fabrication of electrospun nanofibrous PLLA scaffolds}

Nanofibrous poly L- lactic acid (PLLA) scaffolds were fabricated and produced by an electerospinning setup according to a protocol modified with Mohammadi et al., (Mohammadi et al., 2007). PLLA was dissolved in chloroform $(10 \% \mathrm{wt} / \mathrm{wt})$ and added directly to the chloroform $/ \mathrm{N}, \mathrm{N}$ dimethylformamide (DMF) (Sigma, Steinheim, Germany) solution (10:1).PLLA was delivered to metal capillaries with a constant mass flow. For stabilization, the nanofibrous mats were treated with methanol, rinsed with sodium hydroxide solution and deionized water. The nano-structured scaffolds were then freeze-dried and stored in a desiccator at room temperature until use for culturing cells.

\section{Surface modification of nanofiber}

A low frequency plasma generator of $40 \mathrm{KHz}$ frequency with a cylindrical quartz reactor (Diener Electronics, Germany) was used. Pure oxygen was introduced into the reaction chamber of system at 0.4 mbar pressure and purged for $10 \mathrm{~min}$ before beginning of treatment. Then the glow discharge was ignited for $10 \mathrm{~min}$. After termination of treatment, the generator was switched off, and the system was flushed with oxygen gas for $20 \mathrm{~min}$ before venting to atmospheric pressure.

\section{Seeding and differentiation of CJMSCs on PLLA scaffold}

Nanofibrous PLLA scaffolds were placed in $70 \mathrm{~mm}^{2}$ cultures (Corning Glass Works, Corning, NY) and $4 \diamond 10^{5}$ of CJMSCs were seeded on it. Cellular scaffolds were incubated at $37^{\circ} \mathrm{C}$ or $4 \mathrm{~h}$ to allow CJMSCs to diffuse into and adhere to the scaffold before the addition of $20 \mathrm{~mL}$ of culture medium to each plate. During the $4 \mathrm{~h}$ incubation, $20 \mathrm{~mL}$ of serum containing culture medium was applied every $30 \mathrm{~min}$ to each cellular scaffold to prevent the constructs from drying. For neurogenic differentiation, the cells

\section{TABLE 1}

\section{SPECIFIC PRIMERS USED FOR PCR AMPLIFICATION}

\begin{tabular}{|c|c|c|c|}
\hline Genes & Primer sequences & Size (bp) & Accession Number \\
\hline Nestin & $\begin{array}{l}\text { F:GCCCTGACCACTCCAGTTTA } \\
\text { R:GGAGTCCTGGATTTCCTTCC }\end{array}$ & 199 & NM:051373 \\
\hline NSE & $\begin{array}{l}\text { F:AAGGACAAATACGGCAAGGA } \\
\text { R:TGGACCAGGCAGCCCAATC }\end{array}$ & 327 & NM:22349 \\
\hline MAP2 & $\begin{array}{l}\text { F:CCATTTGCAACAGGAAGACAC } \\
\text { R:CAGCTCAAATGCTTTGCAACTAT }\end{array}$ & 428 & NM:002374.3 \\
\hline BTubulinIII & $\begin{array}{l}\text { F:ATGTACGAAGACGACGAGGAG } \\
\text { R:GTATCCCCGAAAATATAAACACA }\end{array}$ & 310 & NM:BC:003021 \\
\hline EN1 & $\begin{array}{l}\text { F:CTGGGTGTACTGCACACGTTAT } \\
\text { R:TACTCGCTCTCGTCTTTGTCCT }\end{array}$ & 356 & NM:001426.3 \\
\hline EN2 & $\begin{array}{l}\text { F:GTGGGTCTACTGTACGCGCT } \\
\text { R:CCTACTCGCTGTCCGACTTG }\end{array}$ & 358 & NM:001427.3 \\
\hline Nurr1 & $\begin{array}{l}\text { F:GCACTTCGGCAGAGTTGAATGA } \\
\text { R:GGTGGCTGTGTTGCTGGTAGTT }\end{array}$ & 491 & NM:001457.2 \\
\hline Ptx3 & $\begin{array}{l}\text { F:TGGGAGTCTGCCTGTTGCAG } \\
\text { R:CAGCGAACCGTCCTCTGGG }\end{array}$ & 213 & NM:005029.3 \\
\hline Pax2 & $\begin{array}{l}\text { F:ATGTTCGCCTGGGAGATTCG } \\
\text { R:GCAAGTGCTTCCGCAAACTG }\end{array}$ & 361 & NM:003989.3 \\
\hline Wnt1 & $\begin{array}{l}\text { F:TAGCCTCCTCCACGAACCTG } \\
\text { R:CAGCCTCGGTTGACGATCTTG }\end{array}$ & 239 & NM:005430.2 \\
\hline Wnt3a & $\begin{array}{l}\text { F:AAGCAGGCTCTGGGCAGCTA } \\
\text { R:GACGGTGGTGCAGTTCCA }\end{array}$ & 234 & NM:033131.2 \\
\hline Wnt5a & $\begin{array}{l}\text { F:ATCCTGACCACTGGAAGCCCTGT } \\
\text { R:GGCTCATGGCGTTCACCAC }\end{array}$ & 358 & NM:003392.3 \\
\hline $\mathrm{TH}$ & $\begin{array}{l}\text { F:GTCCCCTGGTTCCCAAGAAAAGT } \\
\text { R:TCCAGCTGGGGGATATTGTCTTC }\end{array}$ & 333 & NM:000360.3 \\
\hline HPRT1 & $\begin{array}{l}\text { F:CCTGGCGTCGTGATTAGTG } \\
\text { R:TCAGTCCTGTCCATAATTAGTCC }\end{array}$ & 125 & NM:000194.1 \\
\hline
\end{tabular}

were incubated in neurogenic medium consisting of DMEM, supplemented with $0.5 \mathrm{mM}$ isobutyl methyl xanthin (IBMX; Sigma Chemical Co), $1 \mathrm{mM}$ dibutyryl-cAMP (dbcAMP; Sigma Chemical Co), and $10 \mathrm{mM}$ retinoic acid (Sigma Chemical Co) (Nadri et al., 2008) for 6 days. The seeded cells on scaffolds were maintained for 6 days in a humidified incubator at $37^{\circ} \mathrm{C}$ and $5 \%$ CO2 with medium changes every 2 days. The non-seeded cells on scaffold (seeded on tissue culture polystyrene (TCPS) plate) were maintained in neurogenic medium as a control cells.

\section{Scanning electron microscopy (SEM)}

The cell-polymer constructs were fixed in $2.5 \%$ glutaraldehyde, dehydrated through a graded series of ethanol, vacuum dried, mounted onto aluminum stubs, and sputter coated with gold. Samples were examined using a scanning electron microscope (S- 4500; Hitachi, Japan) at an accelerating voltage of $20 \mathrm{kV}$.

\section{RT-PCR analysis}

Total RNA was isolated from cells by using the Nucleospin RNAll kit (Macherey-Nagel, Germany). Prior to reverse transcription (RT), RNA samples were digested with DNase I (EN0521; Fermentas) to remove contaminating genomic DNA. DNase I was dissolved in $10 \mathrm{X}$ reaction buffer with $\mathrm{MgCl} 2$, and $1 \mathrm{u} / \mu$ l of DNase I was added per $1 \mu \mathrm{g}$ of RNA and incubated for $30 \mathrm{~min}$ at $37^{\circ} \mathrm{C}$. DNasel activity was arrested following addition of $1 \mu \mathrm{l}$ of $25 \mathrm{mM}$ EDTA and incubated at $65^{\circ} \mathrm{C}$ for 10 minutes. Standard RT was performed using the RevertAid TM H Minus First Strand cDNA Synthesis Kit (Fermentas) and $2 \mu \mathrm{g}$ total RNA, $0.5 \mu \mathrm{g}$ oligo (dt18) per reaction, according to the manufacture's instructions. Reaction mixtures for PCR, included $2.5 \mu \mathrm{l}$ cDNA, 1x PCR buffer (AMS TM, Sinagen, Iran), $200 \mu \mathrm{M}$ dNTPs, $0.5 \mu \mathrm{M}$ of each of

Forward and Reverse primers and 1 U Taq DNA polymerase (Fermentas, MD, USA). The primers are listed in Table 1. Polymerase chain reactions were performed at $94^{\circ} \mathrm{C}$ for $1 \mathrm{~min}, 25-30$ cycles $94^{\circ} \mathrm{C}$ for $30 \mathrm{~s}, 55-63^{\circ} \mathrm{C}$ for $30 \mathrm{~s}$, and $72^{\circ} \mathrm{C}$ for $30 \mathrm{~s}$ and $72^{\circ} \mathrm{C}$ for 10 minutes. Amplified DNA fragments were electrophoresed on $1.5 \%$ agarose gel. The gels were stained with ethidium bromide $(10 \mu \mathrm{g} / \mathrm{ml})$ and photographed on a UV transilluminator (uvidoc, UK).

\section{Immunocytochemistry analysis}

The cells treated with neurogenic medium fixed by incubation in $1 \%$ paraformaldehyde/PBS for 3-5 min, permeabilized with $0.5 \%$ Triton X-100 in PBS for $10 \mathrm{~min}$, and post-fixed for an additional $10 \mathrm{~min}$ in $4 \%$ paraformaldehyde in PBS. The cells were then reacted with primary antibodies (mouse anti-tyrosine hydroxylase (TH), and Beta-tubulin III (b-Tubulin III, Chemicon) at $4{ }^{\circ} \mathrm{C}$ for $24 \mathrm{~h}$, washed with PBS and reacted with the phycoerythrin (PE), fluorescent isothiocyanate (FITC)-conjugated anti mouse IgG as the secondary antibody (Sigma Chemical Co) at room temperature for $3 \mathrm{~h}$. Then, the cells were washed with PBS-Tween $0.1 \%$ three times and incubated with diaminobenzidine (DAB) solution (Sigma Chemical Co) for $10 \mathrm{~min}$.

\section{Acknowledgment}

We are grateful to Mrs. Amini for Immunocytochemistry analysis. This work was supported by a grant from Stem Cells Technology institute.

\section{References}

ANDRADES, J.A., NIMNI, M.E., HAN, B., ERTL, D.C., HALL, F.L. and BECERRA J. (1996). Type I collagen combined with a recombinant TGF-beta serves as a scaffold for mesenchymal stem cells. Int J Dev Bio/Suppl 1: 107S-108S.

BAKSH, D., SONG, L. and TUAN, R.S. (2004). Adult mesenchymal stem cells: characterization, differentiation, and application in cell and gene therapy. $J \mathrm{Ce} / \mathrm{I}$ Mol Med8: 301-316.

BHANG, S.H., LIM, J.S., CHOI, C.Y., KWON, Y.K. and KIM, B.S. (2007). The behavior of neural stem cells on biodegradable synthetic polymers. J Biomater Sci Polym Ed18: 223-239. 
CANCEDDA, R., DOZIN, B., GIANNONI, P. and QUARTO, R. (2003). Tissue engineering and cell therapy of cartilage and bone. Matrix Bio/22: 81-91.

CAPLAN, A.I. (2000). Tissue engineering designs for the future: new logics, old molecules. Tissue Eng 6: 1-8.

CASTELO-BRANCO, G., WAGNER, J., RODRIGUEZ, F.J., KELE, J., SOUSA, K., RAWAL, N., PASOLLI, H.A., FUCHS, E., KITAJEWSKI, J. and ARENAS, E. (2003). Differential regulation of midbrain dopaminergic neuron development by Wnt-1, Wnt-3a, and Wnt-5a. Proc Nat/ Acad Sci U S A 100: 12747-12752.

CHEN, J., ZHANG, Z.G., LI, Y., WANG, L., XU, Y.X., GAUTAM, S.C., LU, M., ZHU, Z. and CHOPP, M. (2003). Intravenous administration of human bone marrow stromal cells induces angiogenesis in the ischemic boundary zone after stroke in rats. Circ Res 92: 692-699.

CHU, Y., LE, W., KOMPOLITI, K., JANKOVIC, J., MUFSON, E.J. and KORDOWER, J.H. (2006). Nurr1 in Parkinson's disease and related disorders. J Comp Neurol 494: 495-514.

DE BARI, C., DELL'ACCIO, F., TYLZANOWSKI, P. and LUYTEN, F.P. (2001). Multipotent mesenchymal stem cells from adult human synovial membrane. Arthritis Rheum 44: 1928-1942.

DE UGARTE, D.A., MORIZONO, K., ELBARBARY, A., ALFONSO, Z., ZUK, P.A., ZHU, M., DRAGOO, J.L., ASHJIAN, P., THOMAS, B., BENHAIM, P. et al. (2003). Comparison of multi-lineage cells from human adipose tissue and bone marrow. Cells Tissues Organs 174: 101-109.

FLYNN, L.E., PRESTWICH, G.D., SEMPLE, J.L. and WOODHOUSE, K.A. (2008). Proliferation and differentiation of adipose-derived stem cells on naturally derived scaffolds. Biomaterials 29: 1862-1871.

GHASEMI-MOBARAKEH, L., PRABHAKARAN, M.P., MORSHED, M., NASRESFAHANI, M.H. and RAMAKRISHNA, S. (2008). Electrospun poly(epsiloncaprolactone)/gelatin nanofibrous scaffolds for nerve tissue engineering. Biomaterials 29: 4532-4539.

HORWITZ, E.M., GORDON, P.L., KOO, W.K., MARX, J.C., NEEL, M.D., MCNALL, R.Y., MUUL, L. and HOFMANN, T. (2002). Isolated allogeneic bone marrowderived mesenchymal cells engraft and stimulate growth in children with osteogenesis imperfecta: Implications for cell therapy of bone. Proc Natl Acad SCi U S A 99: 8932-8937.

JANKOVIC, J., CHEN, S. and LE, W.D. (2005). The role of Nurr1 in the development of dopaminergic neurons and Parkinson's disease. Prog Neurobio/77: 128-138.

KAN, I., BEN-ZUR, T., BARHUM, Y., LEVY, Y.S., BURSTEIN, A., CHARLOW, T., BULVIK, S., MELAMED, E. and OFFEN, D. (2007). Dopaminergic differentiation of human mesenchymal stem cells-utilization of bioassay for tyrosine hydroxylase expression. Neurosci Lett 419: 28-33.

LANGER, R. and VACANTI, J.P. (1993). Tissue engineering. Science 260: 920926.

MARTINAT, C., BACCI, J.J., LEETE, T., KIM, J., VANTI, W.B., NEWMAN, A.H., CHA, J.H., GETHER, U., WANG, H. and ABELIOVICH, A. (2006). Cooperative transcription activation by Nurr1 and Pit 33 induces embryonic stem cell maturation to the midbrain dopamine neuron phenotype. Proc Natl Acad Sci USA 103: 2874-2879.

MIURA, M., GRONTHOS, S., ZHAO, M., LU, B., FISHER, L.W., ROBEY, P.G. and SHI, S. (2003). SHED: stem cells from human exfoliated deciduous teeth. Proc Natl Acad Sci U S A 100: 5807-5812.

MOHAMMADI, Y., SOLEIMANI, M., FALLAHI-SICHANI, M., GAZME, A., HADDADIASL, V., AREFIAN, E., KIANI, J., MORADI, R., ATASHI, A. and AHMADBEIGI, N. (2007). Nanofibrous poly(epsilon-caprolactone)/poly(vinyl alcohol)/chitosan hybrid scaffolds for bone tissue engineering using mesenchymal stem cells. Int $J$ Artif Organs 30: 204-211.

NADRI, S., SOLEIMANI, M., KIANI, J., ATASHI, A. and IZADPANAH, R. (2008a). Multipotent mesenchymal stem cells from adult human eye conjunctiva stromal cells. Differentiation 76: 223-231.

NADRI, S., SOLEIMANI, M., MOBARRA, Z. and AMINI, S. (2008b). Expression of dopamine-associated genes on conjunctiva stromal-derived human mesenchymal stem cells. Biochem Biophys Res Commun 377: 423-428.

NAKAHARA, H., BRUDER, S.P., HAYNESWORTH, S.E., HOLECEK, J.J., BABER M.A., GOLDBERG, V.M. and CAPLAN, A.I. (1990). Bone and cartilage formation in diffusion chambers by subcultured cells derived from the periosteum. Bone 11: 181-188

NEREM, R.M. (2000). Tissue engineering: confronting the transplantation crisis. Proc Inst Mech Eng [H]214: 95-99.

NGUYEN, L.L. and D'AMORE, P.A. (2001). Cellular interactions in vascular growth and differentiation. Int Rev Cyto/204: 1-48.

NISHIMURA, I., GARRELL, R.L., HEDRICK, M., IIDA, K., OSHER, S. and WU, B. (2003). Precursor tissue analogs as a tissue-engineering strategy. Tissue Eng 9 Suppl 1: S77-S89.

NOORT, W.A., KRUISSELBRINK, A.B., IN'T ANKER, P.S., KRUGER, M., VAN BEZOOIJEN, R.L., DE PAUS, R.A., HEEMSKERK, M.H., LOWIK, C.W., FALKENBURG, J.H., WILLEMZE, R. et al. (2002). Mesenchymal stem cells promote engraftment of human umbilical cord blood-derived CD34(+) cells in NOD/SCID mice. Exp Hemato/30: 870-878.

NOTH, U., OSYCZKA, A.M., TULI, R., HICKOK, N.J., DANIELSON, K.G. and TUAN, R.S. (2002). Multilineage mesenchymal differentiation potential of human trabecular bone-derived cells. J Orthop Res 20: 1060-1069.

ROSEN, E.D. and MACDOUGALD, O.A. (2006). Adipocyte differentiation from the inside out. Nat Rev Mol Cel/ Bio/7: 885-896.

SARUGASER, R., LICKORISH, D., BAKSH, D., HOSSEINI, M.M. and DAVIES, J.E. (2005). Human umbilical cord perivascular (HUCPV) cells: a source of mesenchymal progenitors. Stem Cells 23: 220-229.

SASAKI, M., HONMOU, O., AKIYAMA, Y., UEDE, T., HASHI, K. and KOCSIS, J.D. (2001). Transplantation of an acutely isolated bone marrow fraction repairs demyelinated adult rat spinal cord axons. Glia 35: 26-34.

SCHWARZ, E.J., ALEXANDER, G.M., PROCKOP, D.J. and AZIZI, S.A. (1999). Multipotential marrow stromal cells transduced to produce L-DOPA: engraftment in a rat model of Parkinson disease. Hum Gene Ther 10: 2539-2549.

SHIELDS, K.J., BECKMAN, M.J., BOWLIN, G.L. and WAYNE, J.S. (2004). Mechanical properties and cellular proliferation of electrospun collagen type II. Tissue Eng 10: 1510-1517.

SIMON, H.H., SAUERESSIG, H., WURST, W., GOULDING, M.D. and O'LEARY D.D. (2001). Fate of midbrain dopaminergic neurons controlled by the engrailed genes. J Neurosci21: 3126-3134.

TONTI, G.A. and MANNELLO, F. (2008). From bone marrow to therapeutic applications: different behaviour and genetic/epigenetic stability during mesenchymal stem cell expansion in autologous and foetal bovine sera? Int J Dev Biol 52: 1023-1032.

TUAN, R.S., BOLAND, G. and TULI, R. (2003). Adult mesenchymal stem cells and cell-based tissue engineering. Arthritis Res Ther 5: 32-45.

VACANTI, J.P. and LANGER, R. (1999). Tissue engineering: the design and fabrication of living replacement devices for surgical reconstruction and transplantation. Lancet354 Suppl 1: SI32-SI34.

YANG, F., MURUGAN, R., WANG, S. and RAMAKRISHNA, S. (2005). Electrospinning of nano/micro scale poly(L-lactic acid) aligned fibers and their potential in neural tissue engineering. Biomaterials 26: 2603-2610.

ZUK, P.A., ZHU, M., ASHJIAN, P., DE UGARTE, D.A., HUANG, J.I., MIZUNO, H., ALFONSO, Z.C., FRASER, J.K., BENHAIM, P. and HEDRICK, M.H. (2002). Human adipose tissue is a source of multipotent stem cells. $\mathrm{Mol} \mathrm{Biol} \mathrm{Cel/13:}$ 4279-4295. 


\section{Further Related Reading, published previously in the Int. J. Dev. Biol.}

See Special Issue Pattern Formation edited by Michael K. Richardson and Cheng-Ming Chuong at: http://www.ijdb.ehu.es/web/contents.php?vol=53\&issue=5-6

\section{Epiblast-derived stem cells in embryonic and adult tissues}

Maria P. De-Miguel, Francisco Arnalich-Montiel, Pilar Lopez-Iglesias, Alejandro Blazquez-Martinez and Manuel Nistal Int. J. Dev. Biol. (2009) 53: 1529 - 1540 (doi: 10.1387/ijdb.072413md)

Skin, cornea and stem cells - an interview with Danielle Dhouailly Cheng-Ming Chuong

Int. J. Dev. Biol. (2009) 53: 775-782

Human conjunctival epithelial precursor cells and their progeny in 3D organotypic culture

Alfredo Rosellini, Sandra Papini, Claudio Giannarini, Marco Nardi and Roberto P. Revoltella Int. J. Dev. Biol. (2007) 51: 739-743

An efficient method for isolation of murine bone marrow mesenchymal stem cells Samad Nadri, Masoud Soleimani, Reza H. HosSeni, Mohammad Massumi, Amir Atashi and Reza Izadpanah

Int. J. Dev. Biol. (2007) 51: 723-729

Genetic and epigenetic control of midbrain dopaminergic neuron development C Perrone-Capano and U Di Porzio

Int. J. Dev. Biol. (2000) 44: 679-687

Type I collagen combined with a recombinant TGF-beta serves as a scaffold for mesenchymal stem cells

J A Andrades, M E Nimni, B Han, D C Ertl, F L Hall and J Becerra

Int. J. Dev. Biol. (1996) 40: S107-S108
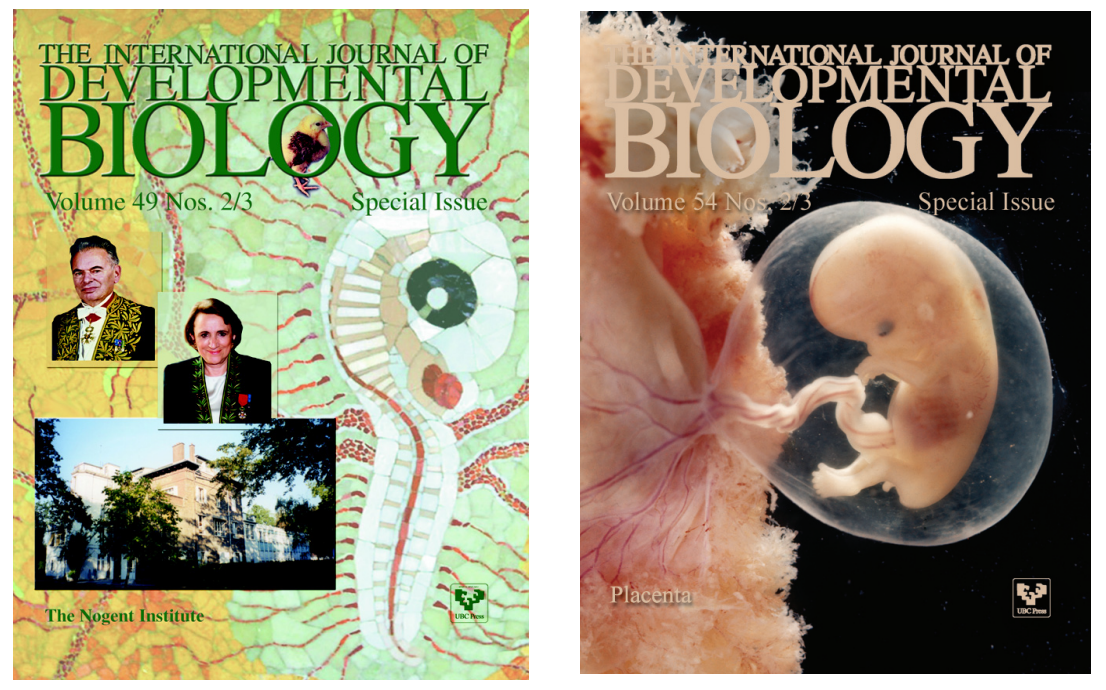

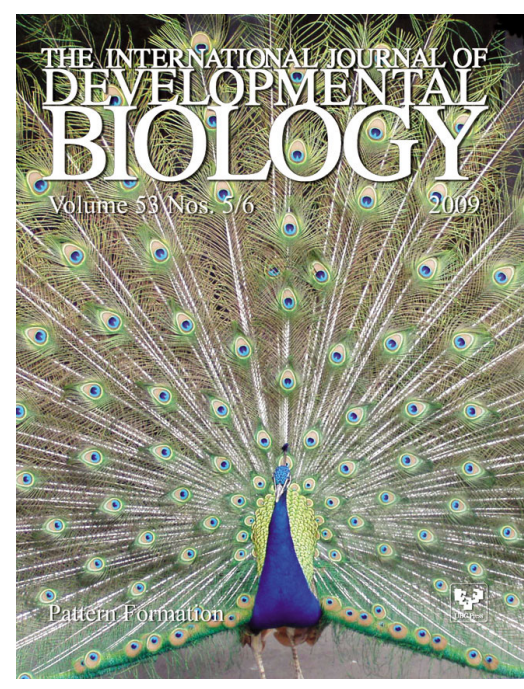

5 yr ISI Impact Factor $(2009)=3.253$
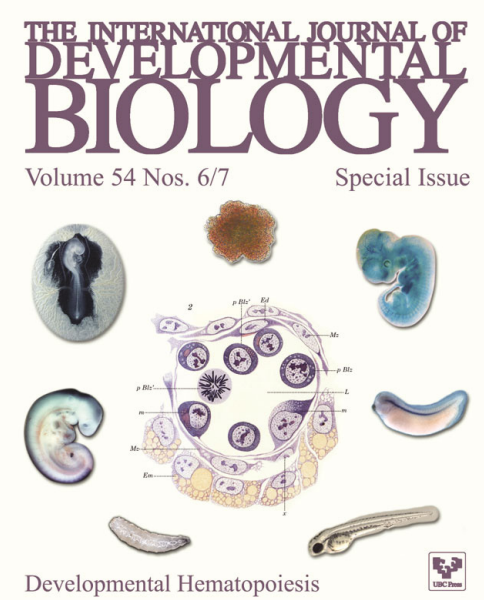